\title{
A Robust Microporous Porphyrin-based Hydrogen-bonded Organic Framework for Highly Selective Separation of C2 Hydrocarbons versus Methane
}

Qi Yin, ${ }^{+, \neq}$Jian Lü,, $\mathcal{S}$ Hong-Fang Li,, Tian-Fu Liu, ${ }^{*}, \neq$ and Rong Cao ${ }^{*},+\neq$

$†$ Department of Chemistry, University of Science and Technology of China, Hefei, Anhui, 230026, P. R. China.

$\ddagger$ State Key Laboratory of Structural Chemistry, Fujian Institute of Research on the Structure of Matter, Chinese Academy of Sciences, Fuzhou, Fujian, 350002, P. R. China.

$\xi$ Fujian Provincial Key Laboratory of Soil Environmental Health and Regulation, College of Resources and Environment, Fujian Agriculture and Forestry University, Fuzhou 350002, P.R. China

$\S$ Samara Center for Theoretical Materials Science (SCTMS), Samara State Technical University, Samara 443100, Russia. 


\section{Table of Content}

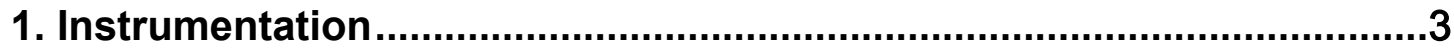

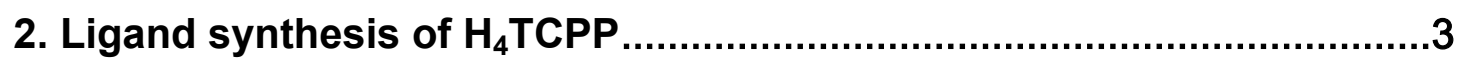

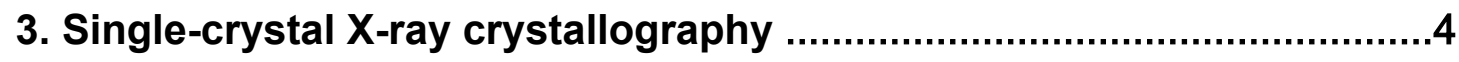

4. Summary of HOFs with permanent porosity ........................................5

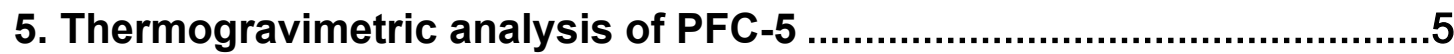

6. Powder X-ray diffraction patterns (PXRD) related with stability test.....6

7. Gas adsorption and selectivity measurements ...............................

7.1 Calculation of the isosteric heats of adsorption ..........................8

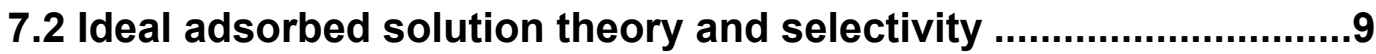




\section{Instrumentation}

${ }^{1} \mathrm{H}-\mathrm{NMR}$ spectra were recorded on Bruker AVANCE III $400 \mathrm{MHz}$ nuclear magnetic resonance spectrometers. Single crystal $X$-ray diffraction data was collected at $273 \mathrm{~K}$ on an Oxford Diffraction SuperNova diffractometer equipped with Cu-Ka radiation ( $\lambda=1.5418$ $\AA$ ). The powder X-ray diffraction (PXRD) was performed on Rikagu Miniflex 600 Benchtop $X$-ray diffraction instrument. The various temperature powder X-ray diffraction (VT-PXRD) was performed on Rikagu Ultima-IV Benchtop X-ray diffraction instrument. The thermogravimetric analysis (TGA) was performed on a Seiko S-II instrument, and the as-synthesized crystalline samples were heated at a rate of $5{ }^{\circ} \mathrm{C} / \mathrm{min}$ up to $700{ }^{\circ} \mathrm{C}$ and then cooled to room temperature under $\mathrm{N}_{2}$ atmosphere. The gas isotherms of the samples were measured using ASAP 2020 from Micromeritics Co. Ltd.

\section{Ligand synthesis of $\mathrm{H}_{4} \mathrm{TCPP}^{1}$}




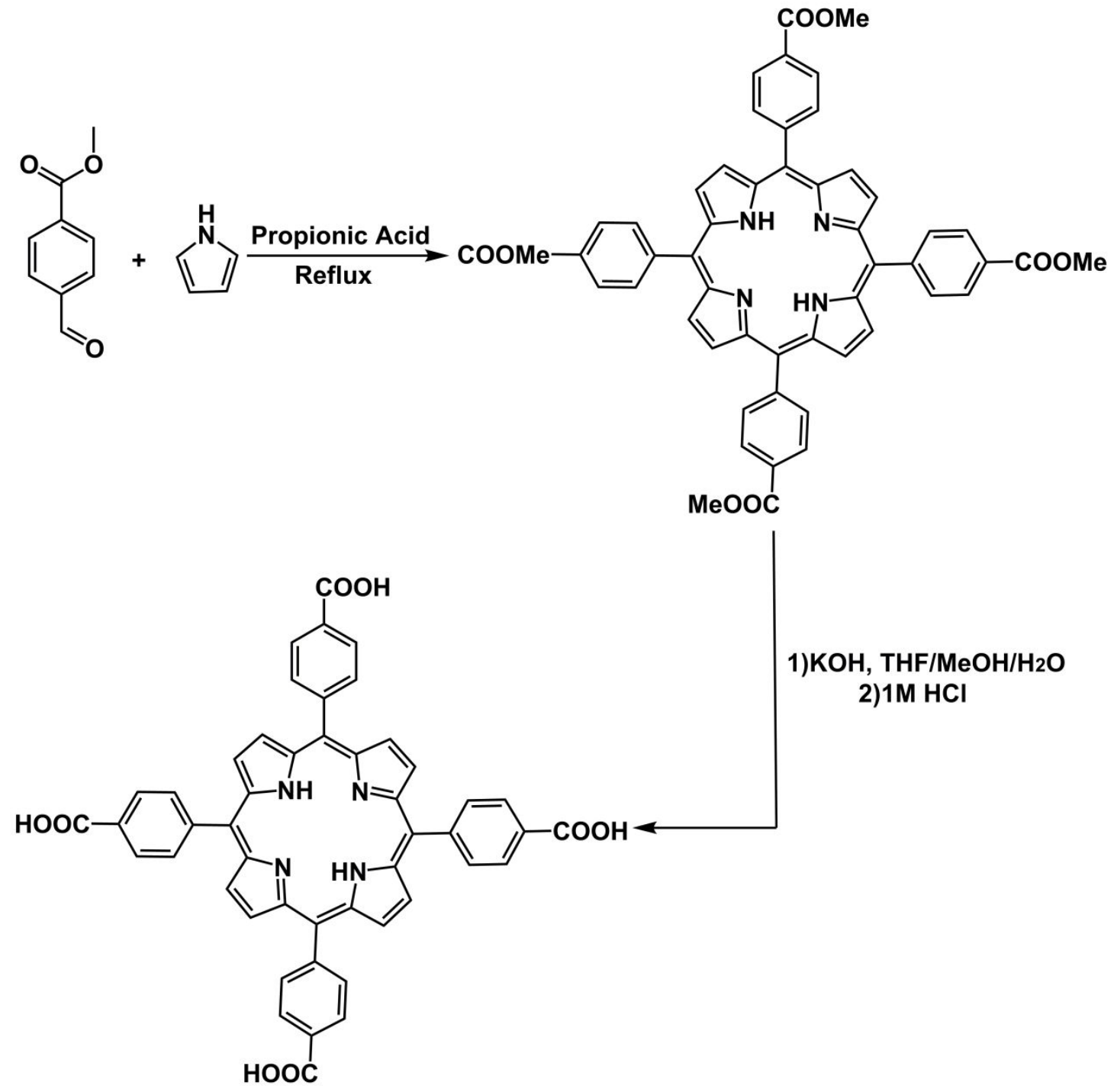

\subsection{5,10,15,20-Tetrakis(4-methoxycarbonylphenyl)porphyrin (TPPCOOMe)}

To refluxed propionic acid $(100 \mathrm{~mL})$ in a $500 \mathrm{~mL}$ three necked flask were added pyrrole (3.0, $0.043 \mathrm{~mol})$ and methyl p-formylbenzoate $(6.9 \mathrm{~g}, 0.042 \mathrm{~mol})$, and the solution was refluxed for $12 \mathrm{~h}$ in darkness. After cooling down the reaction mixture to room temperature, crystals were collected by suction-filtration to afford purple crystals $(1.9 \mathrm{~g}, 2.24 \mathrm{mmol}$, $21.3 \%$ yield). ${ }^{1} \mathrm{H} \mathrm{NMR}\left(300 \mathrm{MHz}, \mathrm{CDCl}_{3}\right) \delta 8.81(\mathrm{~s}, 8 \mathrm{H}), 8.43(\mathrm{~d}, 8 \mathrm{H}), 8.28(\mathrm{~d}, 8 \mathrm{H}), 4.11(\mathrm{~s}$, $12 \mathrm{H}),-2.83(\mathrm{~s}, 2 \mathrm{H})$.

\subsection{5,10,15,20-Tetrakis(4-carboxyphenyl)porphyrin (TCPP)}

TPPCOOMe $(0.75 \mathrm{~g})$ was stirred in THF $(25 \mathrm{~mL})$ and $\mathrm{MeOH}(25 \mathrm{~mL})$ mixed solvent, to which a solution of $\mathrm{KOH}(2.63 \mathrm{~g}, 46.95 \mathrm{mmol})$ in $\mathrm{H}_{2} \mathrm{O}(25 \mathrm{~mL})$ was introduced. This mixture was refluxed for $12 \mathrm{~h}$. After cooling down to room temperature, THF and $\mathrm{MeOH}$ were evaporated. Additional water was added until the solid was fully dissolved, then the homogeneous solution was acidified with $1 \mathrm{M} \mathrm{HCl}$ until no further precipitate was detected. The purple solid was collected by filtration, washed with water and dried in vacuum.

\section{Single-crystal X-ray crystallography}


Single-Crystal X-ray Crystallography. Crystallographic data was collected at $293 \mathrm{~K}$ on an Oxford Diffraction SuperNova diffractometer equipped with Cu-Ka radiation $(\lambda=1.5418)$. The cell refinement and data collection and reduction are solved by CrysAlisPro (Version 1.171.38.41) software package. ${ }^{2}$ The structure was solved by direct method and refined using Olex 2 (Version 1.2.9) ${ }^{3}$ and SHELXL-2014 software package. ${ }^{4,5}$ In addition, the "SQUEEZE" command was employed to dispose of the seriously disordered solvent molecules $(\mathrm{MeOH})$ in pores. Crystal data are summarized in Table S1.

\section{Table S1 Crystal data of the PFC-5}

\begin{tabular}{|c|c|}
\hline Identification code & PFC-5 \\
\hline CCDC number & 1883913 \\
\hline Empirical formula & $\mathrm{C}_{48} \mathrm{H}_{42} \mathrm{~N}_{5} \mathrm{O}_{16}$ \\
\hline Formula weight & 944.86 \\
\hline Temperature/K & 293(2) \\
\hline Crystal system & triclinic \\
\hline Space group & $P-1$ \\
\hline $\mathrm{a} / \AA$ & $9.5071(7)$ \\
\hline $\mathrm{b} / \AA ̊$ & $15.2195(9)$ \\
\hline$c / \AA ̊$ & $18.1208(15)$ \\
\hline$\alpha /^{\circ}$ & $106.222(6)$ \\
\hline$\beta /^{\circ}$ & $102.286(6)$ \\
\hline $\mathrm{Y} /{ }^{\circ}$ & $102.335(6)$ \\
\hline Volume/ $/ \AA^{3}$ & $2353.4(3)$ \\
\hline Z & 2 \\
\hline$\rho_{\text {cald }} / \mathrm{g} \cdot \mathrm{cm}^{-3}$ & 1.333 \\
\hline$\mu / \mathrm{mm}^{-1}$ & 0.856 \\
\hline$F(000)$ & 986.0 \\
\hline Crystal size $/ \mathrm{mm}^{3}$ & $0.4 \times 0.2 \times 0.2$ \\
\hline Radiation & CuKa $(\lambda=1.54184)$ \\
\hline $2 \theta$ range for data collection $/^{\circ}$ & 6.732 to 147.448 \\
\hline Index ranges & $-10 \leq h \leq 11,-18 \leq k \leq 12,-22 \leq \mathrm{I} \leq 21$ \\
\hline Reflections collected & 16548 \\
\hline Independent reflections & $9150\left[R_{\text {int }}=0.0590, R_{\text {sigma }}=0.0824\right]$ \\
\hline Data/restraints/parameters & $9150 / 0 / 544$ \\
\hline Goodness-of-fit on $F^{2}$ & 1.059 \\
\hline Final $R$ indexes $[\mid>=2 \sigma(I)]$ & $R_{1}=0.0588, w R_{2}=0.1614$ \\
\hline Final $R$ indexes [all data] & $R_{1}=0.0940, w R_{2}=0.1759$ \\
\hline Largest diff. peak/hole/e $\bullet \AA^{-3}$ & $0.32 /-0.72$ \\
\hline
\end{tabular}

\section{Summary of HOFs with permanent porosity}

Table S2. HOFs with permanent porosity[a]

\begin{tabular}{cccc}
\hline HOFs & $\begin{array}{c}\mathbf{N}_{2} \text { Uptake } \\
{\left[\mathbf{c m}^{3} / \mathbf{g}\right]}\end{array}$ & $\begin{array}{c}\mathbf{S A}_{\text {BET }} \\
{\left[\mathbf{m}^{2} / \mathbf{g}\right]}\end{array}$ & Ref. \\
\hline TTBI & 754 & 2796 & 6 \\
\hline
\end{tabular}




\begin{tabular}{cccc}
\hline PFC-1 & 613.3 & 2122 & 7 \\
HOF-TCPB & 535 & 2066 & 8 \\
tcpb & 266 & 1095 & 9 \\
SOF-7a & $143^{[\mathrm{c}]}$ & $474^{[\mathrm{d}]}$ & 10 \\
HOF-1a & - & $359.2^{[\mathrm{b}]}$ & 11 \\
HOF-4a & - & $312^{[\mathrm{b}]}$ & 12 \\
PFC-5 & - & $256^{[\mathrm{b}]}$ & This work \\
HOF-2a & - & $237.6^{[\mathrm{b}]}$ & 13 \\
HOF-3a & - & $165^{[\mathrm{b}]}$ & 14 \\
P5-SOF & $\sim 226$ & 97 & 15 \\
\hline
\end{tabular}

[a]BET calculated from the $\mathrm{N}_{2}$ Uptake at $77 \mathrm{~K}$.

[b] Calculated by the $\mathrm{CO}_{2}$ uptake at $195 \mathrm{~K}$.

${ }^{[c]}$ Calculated from $\mathrm{N}_{2}$ isotherm at $125 \mathrm{~K}$.

${ }^{[d]}$ Calculated by the $\mathrm{CO}_{2}$ uptake at $273 \mathrm{~K}$.

5. Thermogravimetric analysis of PFC-5 


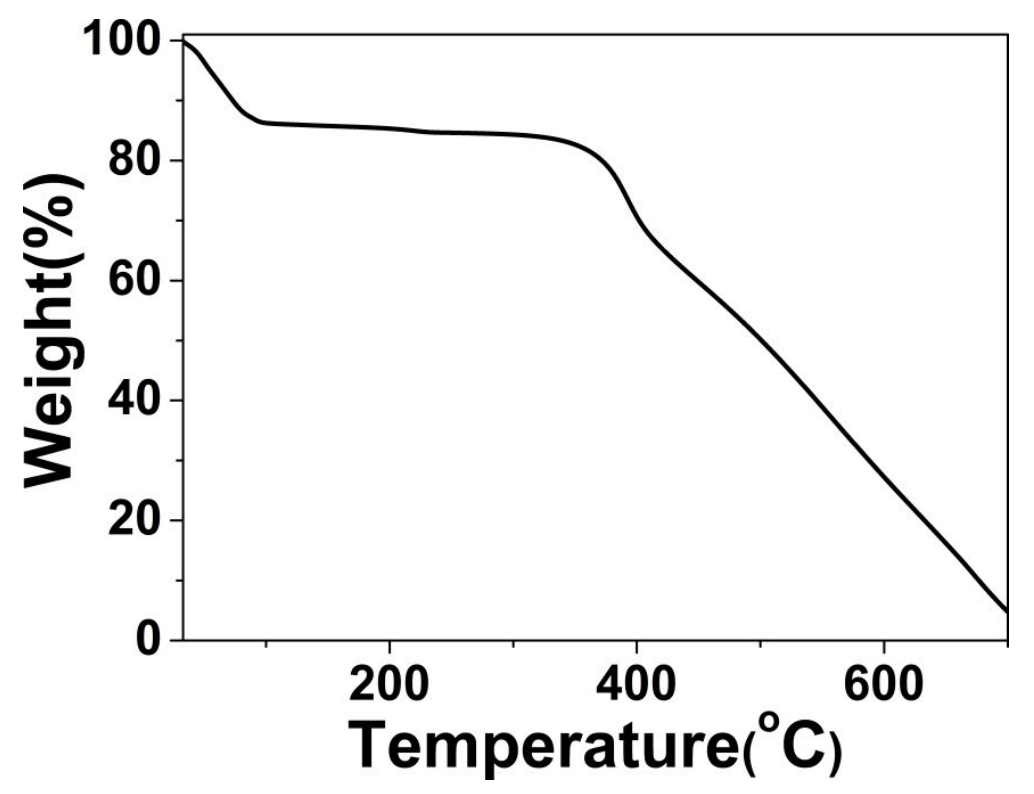

Figure S1 TGA curve of as-synthesized PFC-5.

6. Powder X-ray diffraction patterns (PXRD) related with stability test.

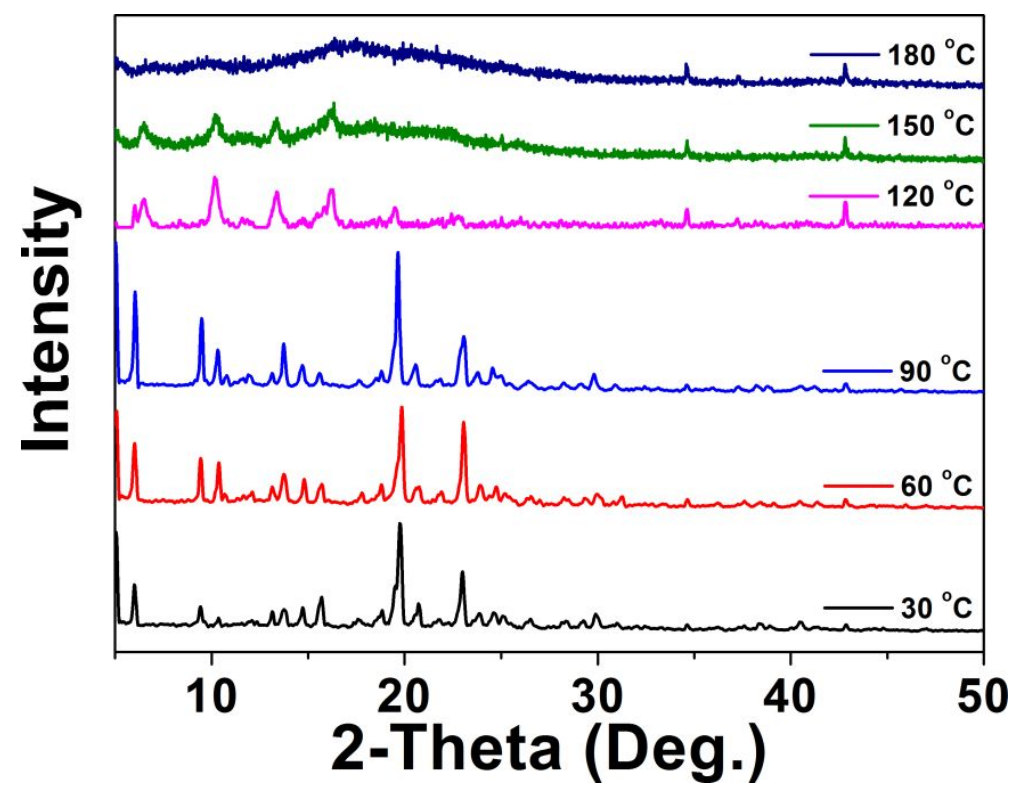

Figure S2 Variable temperature powder X-ray diffraction (VT-PXRD) patterns of as-synthesized PFC- 5 (patterns were recorded from $5^{\circ}$ to $50^{\circ}$ of $2 \theta$ with the scan rate of 5 $\% / \mathrm{min}$ from $30^{\circ} \mathrm{C}$ to $\left.180^{\circ} \mathrm{C}\right)$. 


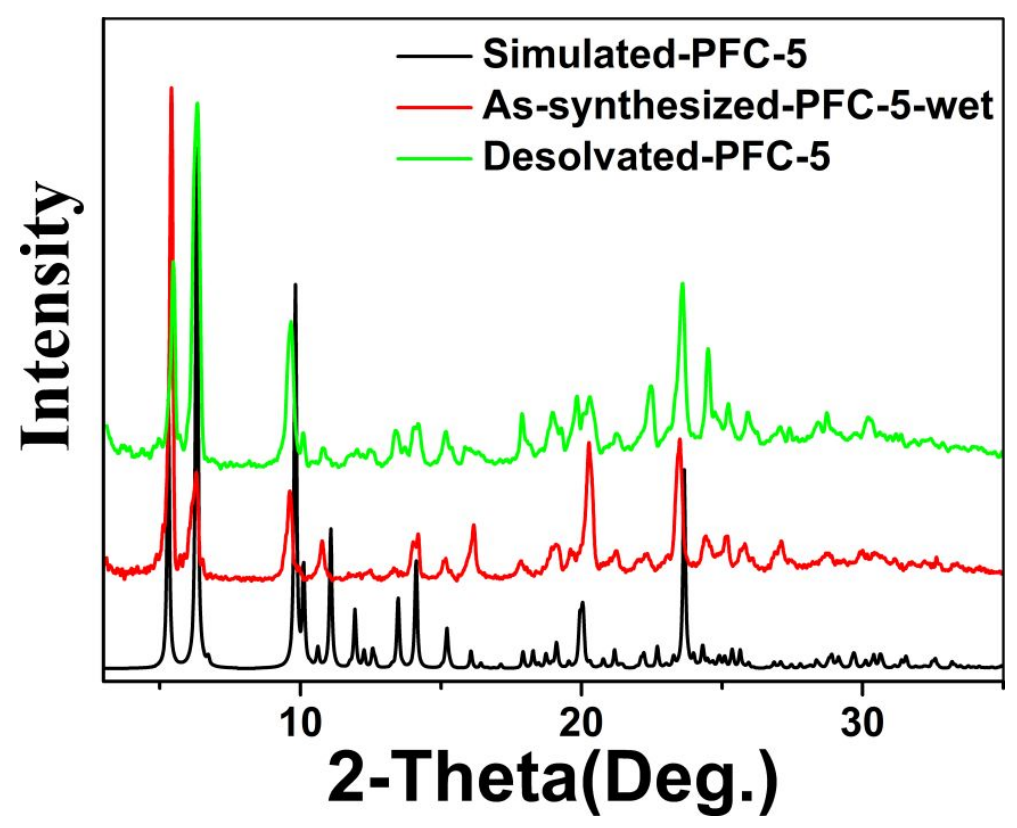

Figure S3 PXRD patterns of simulated-PFC-5 (black), wet as-synthesized-PFC-5 (red) and desolvated-PFC-5 (green).

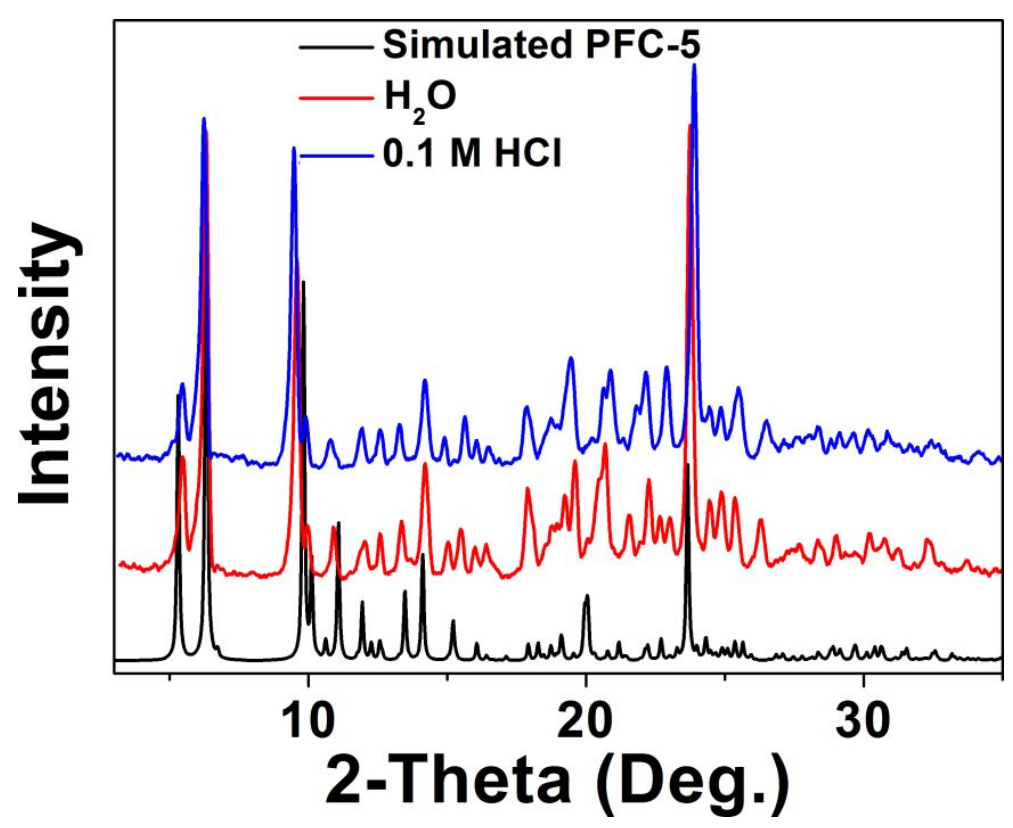

Figure S4 PXRD patterns of PFC-5 after being treated with $\mathrm{H}_{2} \mathrm{O}(\mathrm{red})$ and $0.1 \mathrm{M} \mathrm{HCl}$ (blue) for 1 day. 


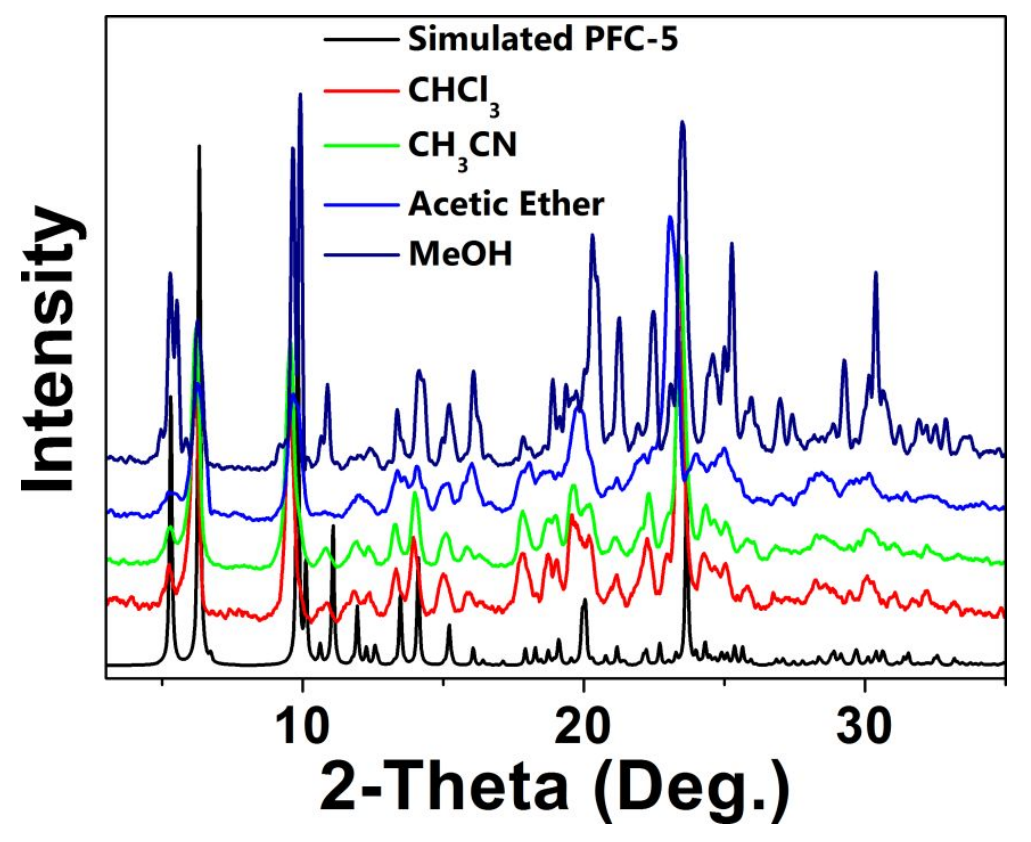

Figure S5 PXRD patterns of PFC-5 after being treated with different solvents for 1 day.

\section{Gas adsorption and selectivity measurements}

\subsection{Calculation of the isosteric heats of adsorption ${ }^{16,17}$}

The isosteric heats of adsorption (Qst) of $\mathrm{CH}_{4}, \mathrm{C}_{2} \mathrm{H}_{2}$, and $\mathrm{C}_{2} \mathrm{H}_{4}$ for PFC-5 were estimated from the sorption data measured at 273 and $298 \mathrm{~K}$ by the virial method:

Virial Method

$\ln (\mathrm{P})=\ln (\mathrm{N})+\left(\frac{1}{T}\right) \sum_{i=0}^{m} a_{i} * N^{i}+\sum_{i=0}^{n} b_{i} * N^{i}$

$\mathrm{N}$ : Uptake capacity $(\mathrm{mg} / \mathrm{g})$

$\mathrm{P}$ : Pressure $(\mathrm{mmHg})$

$\mathrm{T}$ : Temperature $(\mathrm{K})$

$a_{i}, b_{i}:$ Virial coefficients

$m, n$ : Number of coefficients required to adequately describe the isotherms ( $m$ and $n$ were gradually increased until the contribution of extra added $a$ and $b$ coefficients was deemed to be statistically insignificant towards the overall fit, and the average value of the squared deviations from the experimental values was minimized)

The isosteric enthalpy of adsorption (Qst) :

$Q_{s t}=-R * \sum_{i=0}^{m} a_{i} * N^{i}$

R: Universal gas constant $8.314 \mathrm{~J} \cdot \mathrm{mol}^{-1} \cdot \mathrm{K}^{-1}$

The Virial method is a standard method for calculation of coverage-dependent Qst using measured temperature-pressure-coverage isotherm data points. The Qst at very low surface coverage has a quite large error because the adsorption apparatus cannot work 
well at very low pressure (e.g. low accuracy of the pressure gauges, leaking, etc.).

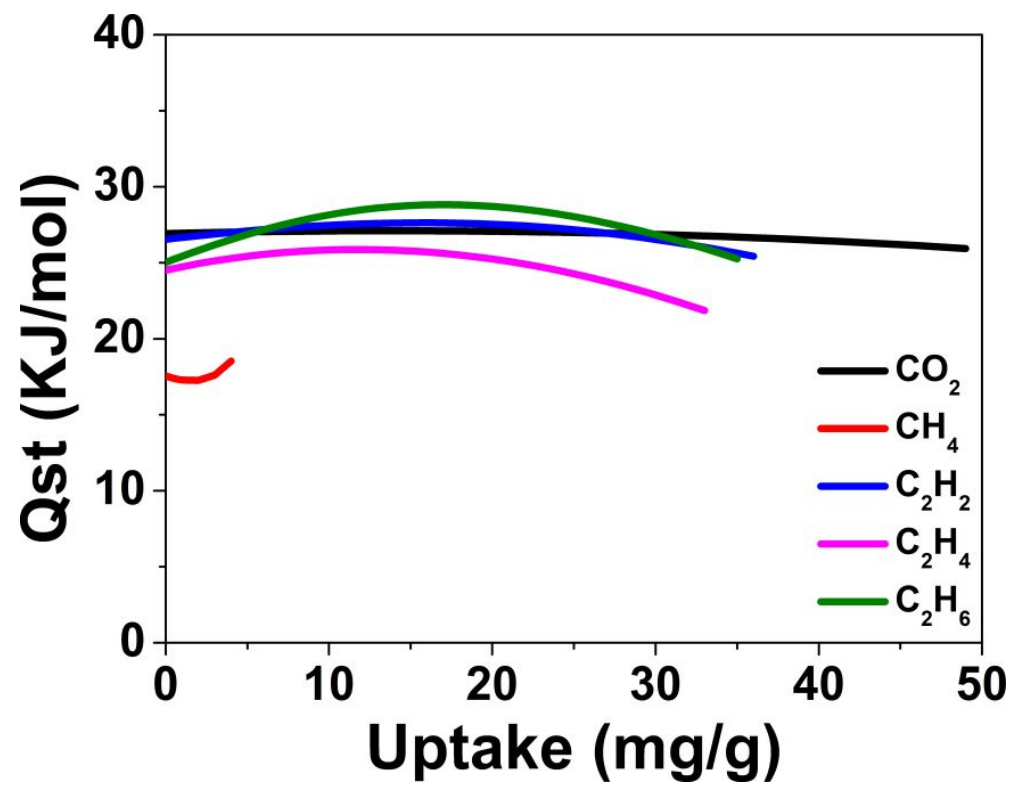

Figure S6 Loading dependent isosteric heat (Qst) of adsorption for PFC-5. The Qst values were calculated based on adsorption isotherms at $273 \mathrm{~K}$ and $298 \mathrm{~K}$ by using the Virial method.

\subsection{Ideal adsorbed solution theory and selectivity ${ }^{18}$}

In ideal adsorbed solution theory (IAST), the adsorption isotherm of pure gas is fitted by the single-site Langmuir-Freundlich equation.

$$
\mathrm{Y}=\left(\mathrm{A} 1 * \mathrm{~b} 1 * \mathrm{x}^{c 1}\right) /\left(1+b 1 * x^{c 1}\right)
$$

$\mathrm{Y}$ : molar loading of species, $\mathrm{mmol} / \mathrm{g}$

A1: saturation capacity of species, $\mathrm{mmol} / \mathrm{g}$

b1: constant, $\mathrm{Pa}^{-1}$

$\mathrm{x}$ : pressure of the bulk gas at equilibrium with the adsorbed phase, $\mathrm{kPa}$

c1: constant

The adsorption selectivity is defined as follow:

$S=\left(\frac{q 1}{q 2}\right) /\left(\frac{p 1}{p 2}\right)$

S: adsorption selectivity for binary mixtures of components 1 and 2

q1, q2: the molar loading of species 1 and $2, \mathrm{mmol} / \mathrm{g}$

p1, p2: the partial pressure of species 1 and 2, mbar

\section{Reference}

(1) Asano, N.; Uemura, S.; Kinugawa, T.; Akasaka, H.; Mizutani, T., Synthesis of biladienone and bilatrienone by coupled oxidation of tetraarylporphyrins. J. Org. Chem. 2007, 72, 
(14), 5320-5326.

(2) Crysalispro verson 1.171.38.41. Rigaku Oxford Diffraction 2015.

(3) Dolomanov, O. V.; Bourhis, L. J.; Gildea, R. J.; Howard, J. A. K.; Puschmann, H., Olex2: A complete structure solution, refinement and analysis program. J. Appl. Crystallogr. 2009, 42, (2), 339-341.

(4) Sheldrick, G. M., Crystal structure refinement with shelxl. Acta Crystallogr. C 2015, 71, (1), 3-8.

(5) Burla, M. C.; Caliandro, R.; Camalli, M.; Carrozzini, B.; Cascarano, G. L.; De Caro, L.; Giacovazzo, C.; Polidori, G.; Siliqi, D.; Spagna, R., II milione: A suite of computer programs for crystal structure solution of proteins. J. Appl. Crystallogr. 2007, 40, (3), 609-613.

(6) Mastalerz, M.; Oppel, I. M., Rational construction of an extrinsic porous molecular crystal with an extraordinary high specific surface area. Angew. Chem. Int. Ed. Engl. 2012, 51, (21), 5252-5255.

(7) Yin, Q.; Zhao, P.; Sa, R. J.; Chen, G. C.; Lu, J.; Liu, T. F.; Cao, R., An ultra-robust and crystalline redeemable hydrogen-bonded organic framework for synergistic chemo-photodynamic therapy. Angew Chem Int Ed Engl 2018, 57, (26), 7691-7696.

(8) Hu, F.; Liu, C.; Wu, M.; Pang, J.; Jiang, F.; Yuan, D.; Hong, M., An ultrastable and easily regenerated hydrogen-bonded organic molecular framework with permanent porosity. Angew. Chem. Int. Ed. Engl. 2017, 56, (8), 2101-2104.

(9) Zentner, C. A.; Lai, H. W.; Greenfield, J. T.; Wiscons, R. A.; Zeller, M.; Campana, C. F.; Talu, O.; FitzGerald, S. A.; Rowsell, J. L., High surface area and $z^{\prime}$ in a thermally stable 8-fold polycatenated hydrogen-bonded framework. Chem. Commun. 2015, 51, (58), 11642-11645.

(10) Lu, J.; Perez-Krap, C.; Suyetin, M.; Alsmail, N. H.; Yan, Y.; Yang, S.; Lewis, W.; Bichoutskaia, E.; Tang, C. C.; Blake, A. J.; Cao, R.; Schroder, M., A robust binary supramolecular organic framework (SOF) with high $\mathrm{CO} 2$ adsorption and selectivity. J. Am. Chem. Soc. 2014, 136, (37), 12828-12831.

(11) He, Y.; Xiang, S.; Chen, B., A microporous hydrogen-bonded organic framework for highly selective $\mathrm{C} 2 \mathrm{H} 2 / \mathrm{C} 2 \mathrm{H} 4$ separation at ambient temperature. J. Am. Chem. Soc. 2011, 133, (37), 14570-14573.

(12) Li, P.; He, Y.; Arman, H. D.; Krishna, R.; Wang, H.; Weng, L.; Chen, B., A microporous six-fold interpenetrated hydrogen-bonded organic framework for highly selective separation of $\mathrm{C} 2 \mathrm{H} 4 / \mathrm{C} 2 \mathrm{H} 6$. Chem. Commun. 2014, 50, (86), 13081-13084.

(13) Li, P.; He, Y.; Guang, J.; Weng, L.; Zhao, J. C.; Xiang, S.; Chen, B., A homochiral microporous hydrogen-bonded organic framework for highly enantioselective separation of secondary alcohols. J. Am. Chem. Soc. 2014, 136, (2), 547-549.

(14) Li, P.; He, Y.; Zhao, Y.; Weng, L.; Wang, H.; Krishna, R.; Wu, H.; Zhou, W.; O'Keeffe, M.; Han, Y.; Chen, B., A rod-packing microporous hydrogen-bonded organic framework for highly selective separation of $\mathrm{C} 2 \mathrm{H} 2 / \mathrm{CO} 2$ at room temperature. Angew. Chem. Int. Ed. Engl. 2015, 54, (2), 574-577.

(15) Tan, L. L.; Li, H.; Tao, Y.; Zhang, S. X.; Wang, B.; Yang, Y. W., Pillar[5]arene-based supramolecular organic frameworks for highly selective CO2-capture at ambient conditions. Adv. Mater. 2014, 26, (41), 7027-7031. 
(16) Rowsell, J. L.; Yaghi, O. M., Effects of functionalization, catenation, and variation of the metal oxide and organic linking units on the low-pressure hydrogen adsorption properties of metal-organic frameworks. J. Am. Chem. Soc. 2006, 128, (4), 1304-1315.

(17) Builes, S.; Sandler, S. I.; Xiong, R., Isosteric heats of gas and liquid adsorption. Langmuir 2013, 29, (33), 10416-10422.

(18) Myers, A. L.; Prausnitz, J. M., Thermodynamics of mixed-gas adsorption. AlChE J. 1965, 11, (1), 121-127. 